\title{
Multivariate analysis of sludge disintegration by microwave-hydrogen peroxide pretreatment process
}

\author{
Ya-wei Wang, Cheng-min Gui, Xiao-tang Ni, Mei-xue Chen, Yuan-song Wei* \\ Research Center for Eco-Environmental Sciences, Chinese Academy of Sciences, P.O. Box 2871, Beijing 100085, PR China
}

\section{H I G H L I G H T S}

- Investigation of TSS, $\mathrm{H}_{2} \mathrm{O}_{2}$ dosage, $\mathrm{pH}$ and interactions on MW sludge pretreatment.

- Quadratic models were drawn for 16 response variables with good predictive ability.

- Models could optimize the treatment process for multiple disintegration objectives.

\section{A R T I C L E I N F O}

\section{Article history:}

Received 31 July 2014

Received in revised form

23 September 2014

Accepted 12 October 2014

Available online 27 October 2014

\section{Keywords:}

Hydrogen peroxide

Microwave

Response surface methodology (RSM)

Sludge disintegration

\begin{abstract}
A B S T R A C T
Microwave irradiation (with $\mathrm{H}_{2} \mathrm{O}_{2}$ ) has been shown to offer considerable advantages owing to its flexible control, low overall cost, and resulting higher soluble chemical oxygen demand (SCOD); accordingly, the method has been proposed recently as a means of improving sludge disintegration. However, the key factor controlling this sludge pretreatment process, $\mathrm{pH}$, has received insufficient attention to date. To address this, the response surface approach (central composite design) was applied to evaluate the effects of total suspended solids (TSS, $2-20 \mathrm{~g} / \mathrm{L}$ ), $\mathrm{pH}(4-10)$, and $\mathrm{H}_{2} \mathrm{O}_{2}$ dosage $(0-2 \mathrm{w} / \mathrm{w}$ ) and their interactions on 16 response variables (e.g., $\mathrm{SCOD}_{\text {released, }} \mathrm{pH}, \mathrm{H}_{2} \mathrm{O}_{2}$ remaining). The results demonstrated that all three factors affect sludge disintegration significantly, and no pronounced interactions between response variables were observed during disintegration, except for three variables (TCOD, TSS remaining, and $\mathrm{H}_{2} \mathrm{O}_{2}$ remaining). Quadratic predictive models were constructed for all 16 response variables $\left(R^{2}: 0.871-0.991\right)$. Taking soluble chemical oxygen demand (SCOD) as an example, the model and coefficients derived above were able to predict the performance of microwave pretreatment (enhanced by $\mathrm{H}_{2} \mathrm{O}_{2}$ and pH adjustment) from previously published studies. The predictive models developed were able to optimize the treatment process for multiple disintegration objectives.
\end{abstract}

(c) 2014 Elsevier B.V. All rights reserved.

\section{Introduction}

Conventional biological wastewater treatment processes, when applied widely, produce vast amounts of waste activated sludge (WAS), the treatment and disposal of which are difficult and expensive for municipal wastewater treatment plants (WWTPs). However, WAS is gaining prominence as a potential bio-resource, although sludge reutilization is impeded by factors such as the protective cell walls and matrix of extracellular polymeric substance (EPS). To overcome these obstacles, sludge pretreatment technologies have been developed incrementally in several previous studies $[1,2]$. Pretreated sludge has been demonstrated to be suitable for many purposes, including the following: (1) enhancing anaerobic

\footnotetext{
* Corresponding author. Tel.: +86 1062849690; fax: +86 1062849690

E-mail address: Yswei@rcees.ac.cn (W. Yuan-song).
}

digestion of WAS to improve biogas production [3-5] or energy recovery by microbial fuel cells [6]; (2) recovering nutrients (nitrogen and phosphorus) or material resources (e.g., proteins, VFAs for the production of polyhydroxyalkanoates) from sludge [7]; (3) improving sludge dewatering to promote reduction in sludge volume or sludge disinfection [8]; and (4) reducing sludge production by cryptic growth $[9,10]$.

Methods for sludge disintegration by mechanical [11], thermal [12], and chemical [13] treatment have been proposed previously. Microwave (MW) pretreatment, which offers advantages such as the rapid application of direct heat and reduction of energy losses, is an alternative method to conventional thermal pretreatment and has garnered increasing attention recently [14,15]. In particular, microwave pretreatment was found to be superior to thermal treatment in terms of sludge solubilization and biogas production [16]. Moreover, changes in the dipole orientation of polar molecules occur during microwave irradiation, producing athermal 
(or non-thermal) effects [17]. For the solubilization of waste activated sludge, the effectiveness of microwave irradiation is affected by several factors, which have been investigated extensively [3]; such factors include MW output power [10,18], target temperature [19], and sludge concentrations [20,21]. However, investigation of these factors through conventional "change one factor at a time" methods have some shortcomings, including that these methods are laborious, time-consuming, and incapable of obtaining true optimal values owing to their inability to consider interactions among variables. Therefore, three-factor fixed-effect analysis of variance (ANOVA) determination has been adopted to evaluate the effects of high temperature $\left(110-175^{\circ} \mathrm{C}\right)$, MW intensity $(1.25$ and $3.75^{\circ} \mathrm{C} / \mathrm{min}$ ), and sludge concentration ( 6 and $11.85 \%$ ) on the solubilization of sludge [22]; the interaction of these factors was found to be significant at the $94 \%$ confidence interval. Moreover, the effects of heating pretreatment on the degree of solubilization of waste activated sludge are investigated using response surface analysis [21], and the conditions required to produce a maximum solubilization degree of $17.9 \%$ were predicted to be $400 \mathrm{~W}$ (output power $400-1600 \mathrm{~W}), 102^{\circ} \mathrm{C}$ (target temperature $60-120^{\circ} \mathrm{C}$ ), and $2.3 \%$ TS (total solid concentration, $1-3 \%$ ).

The addition of $\mathrm{H}_{2} \mathrm{O}_{2}$ in a closed-vessel MW digestion system has been reported to enhance the pretreatment of sludge markedly [23], and such advanced oxidation processes (AOPs) appear to offer promise as suitable technologies for the minimization [24] and pasteurization and stabilization [25] of excess sludge. $\mathrm{A}_{2} \mathrm{O}_{2}$ dosing strategy to inhibit the adverse effects of catalase at low temperatures in an open system was developed in our previous work [26]. To optimize the microwave-enhanced advanced oxidation process $\left(\mathrm{MW} / \mathrm{H}_{2} \mathrm{O}_{2}-\mathrm{AOP}\right.$ ), screening experiments (four factors: temperature, hydrogen peroxide dosage, mixing, and solids concentration) were conducted [20]; appropriate solids disintegration and nutrient release were determined to occur at $120^{\circ} \mathrm{C}$ and $0.80 \mathrm{~g} \mathrm{H}_{2} \mathrm{O}_{2} / \mathrm{g}$ dry sludge. Yin et al. [27] found initial sludge TS content and hydrogen peroxide dosage were the most significant factors controlling nutrient solubilization (i.e., more significant than heating temperature and heating time), maximum solubilization was obtained for $2.5 \% \mathrm{TS}, 2 \mathrm{wt} \%$ hydrogen peroxide, and $5 \mathrm{~min}$ of microwave heating at $120^{\circ} \mathrm{C}$.

Microwave- $\mathrm{H}_{2} \mathrm{O}_{2}$ has been reported to perform better in substrate degradation under acidic and neutral conditions [28]. Moreover, the effects of acids (e.g., $\mathrm{HCl}$ and $\mathrm{H}_{2} \mathrm{SO}_{4}$ ) on sludge disintegration have been shown to enhance the release of ammonia [29]. Microwave-enhanced advanced oxidation processes have been adopted previously for the treatment of dairy manure at low $\mathrm{pH}$ [30]; such low-pH methods are known to offer advantages such as enhanced phosphorous release and promotion of the dewatering of sludge [31]. Conversely, combined MW irradiation $\left(160^{\circ} \mathrm{C}\right)$ with an alkaline pretreatment method (using $\mathrm{NaOH}, \mathrm{pH} \sim 12.5$ ) demonstrated that this technique could increase the solubilization ratio (in terms of SCOD/TCOD) to 0.37 [3].

Recently, Hong et al. [28] found that the degradation of rhodamine $\mathrm{B}(\mathrm{RhB})$ and methylene blue $(\mathrm{MB})$ in the $\mathrm{MW}-\mathrm{H}_{2} \mathrm{O}_{2}$ system was very competitive at extreme alkaline $\mathrm{pH}$, suggesting that this may be an appropriate means of promoting degradation under highly alkaline conditions; this result is encouraging for the development of MW- $\mathrm{H}_{2} \mathrm{O}_{2}$ technology in alkaline wastewater treatment. Similarly, it has been shown that high pH may enhance the MW thermal effect, making MW techniques more suitable for application in sludge disintegration [15]. However, few studies to date have investigated the microwave- $\mathrm{H}_{2} \mathrm{O}_{2}$ system under alkali conditions.

A priori, and on the basis of a literature survey on MW and AOPs [23-28], TSS, $\mathrm{H}_{2} \mathrm{O}_{2}$, and $\mathrm{pH}$ were known to be the critical factors controlling sludge disintegration at mild temperatures $\left(100^{\circ} \mathrm{C}\right)$ [32]; however, the effect of $\mathrm{pH}$ (from acidic to basic) has not yet been fully recognized. In addition, the interactions among these three factors remain unclear. Moreover, the majority of previous researches have focused on the treatment of target sludge, neglecting the behavior of the oxidant $\mathrm{H}_{2} \mathrm{O}_{2}$ during this process. In practical engineering applications of this technology, it is always designed to achieve multi-objectives for the sludge disintegration unit; for example, the sludge can be treated to release more organic matter and less heavy metal. If recovery of N/P in the form of struvite is to be considered, phosphate and ammonia (and $\mathrm{Mg}^{2+}$ ) release should be maximized, whereas the release of $\mathrm{Ca}^{2+}$ (which acts as an inhibitor) should be minimized. Therefore, there is great demand for a unifying predictive model that incorporates the above aspects of sludge pretreatment and will allow simultaneous quantitative evaluation of sludge disintegration and optimization of $\mathrm{MW}-\mathrm{H}_{2} \mathrm{O}_{2}$ sludge pretreatment by $\mathrm{pH}$ adjustment for multi-objectives.

Response surface methodology (RSM) is a powerful statistical tool used to construct models and evaluate the influences of several individual factors and their interactions simultaneously. Accordingly, RSM has emerged as an important tool in the study of multifactor interaction. Typically, predictive models have been used to analyze and optimize operation parameters, thus allowing desirable responses to be attained while reducing the number of experiments.

The present study adopted multivariate analysis to investigate sludge disintegration and aimed to achieve the following: (1) investigate the effects of $\mathrm{pH}$ in isolation and in conjunction with uniform initial sludge concentration and $\mathrm{H}_{2} \mathrm{O}_{2}$ dosage, and assess the interactions among these factors during sludge disintegration based on RSM and 16 response variables; and (2) construct a unifying model to predict sludge solubilization and $\mathrm{H}_{2} \mathrm{O}_{2}$ usage, thus providing a simple way to estimate optimal values for multiple sludge pretreatment objectives.

\section{Materials and methods}

\subsection{Raw materials}

The WAS was obtained from returned sludge from the secondary settling tank of the Fangzhuang municipal wastewater treatment plant (WWTP), with a design capacity of $40,000 \mathrm{~m}^{3} /$ day, in Beijing, China. This WWTP was an $A^{2} / O$ process plant and operated with sludge retention time (SRT) of approximately 15 days. The high VSS to TSS ratio in the sludge (79\%) indicates that it consisted mainly of organic substances. Waste activated sludge was centrifuged before use and washed three times to avoid the interference of soluble matter. The sludge was stored at concentrations of $3 \%$ at $4{ }^{\circ} \mathrm{C}$ and diluted with distilled water prior to use to provide various set concentrations.

\subsection{Experimental design}

The effects of the studied variables (TSS, $\mathrm{pH}, \mathrm{H}_{2} \mathrm{O}_{2}$ dosage) and their interactions on the response variables were investigated using a central composite design (CCD) method. The CCD method adopted allows the development of mathematical equations. TSS $\left(X_{1}\right), \mathrm{pH}$ $\left(X_{2}\right)$, and the $\mathrm{H}_{2} \mathrm{O}_{2}$ to sludge ratio $\left(X_{3}\right)$ were varied over the ranges 3-20 g/L, 2-12, and $0-2(\mathrm{w} / \mathrm{w})$, respectively, with corresponding central values of $11.5 \mathrm{~g} / \mathrm{L}\left(X_{1}\right), 7\left(X_{2}\right)$, and $1.0\left(X_{3}\right) . X_{i}$ denotes the real value of the three variables according to the experimental design (Table 1, actual values). The parameters were standardized according to the following equation.

$x_{i}=\frac{X_{i}-X_{i}^{o}}{\Delta X_{i}}$

where $x_{i}$ was the coded value of the variable $X_{i}, X_{i}^{o}$ was the value of $X_{i}$ at the center point of the investigated area, and $\Delta X_{i}$ was the 
Table 1

Matrix of experimental design and results.

\begin{tabular}{|c|c|c|c|c|c|c|}
\hline \multirow[t]{2}{*}{ Run } & \multicolumn{3}{|c|}{ Coded values } & \multicolumn{3}{|l|}{ Actual values } \\
\hline & $\operatorname{TSS}\left(x_{1}\right)$ & $\mathrm{pH}\left(x_{2}\right)$ & $\mathrm{H}_{2} \mathrm{O}_{2}\left(x_{3}\right)$ & $\operatorname{TSS}\left(X_{1}, \mathrm{~g} / \mathrm{L}\right)$ & $\mathrm{pH}\left(X_{2}\right)$ & $\mathrm{H}_{2} \mathrm{O}_{2}\left(X_{3}\right)$ \\
\hline 1 & -1 & -1 & -1 & 6.44 & 5.22 & 0.40 \\
\hline 2 & 1 & -1 & -1 & 16.55 & 5.22 & 0.40 \\
\hline 3 & -1 & 1 & -1 & 6.44 & 8.78 & 0.40 \\
\hline 4 & 1 & 1 & -1 & 16.55 & 8.78 & 0.40 \\
\hline 5 & -1 & -1 & 1 & 6.44 & 5.22 & 1.59 \\
\hline 6 & 1 & -1 & 1 & 16.55 & 5.22 & 1.59 \\
\hline 7 & -1 & 1 & 1 & 6.44 & 8.78 & 1.59 \\
\hline 8 & 1 & 1 & 1 & 16.55 & 8.78 & 1.59 \\
\hline 9 & -1.68 & 0 & 0 & 3.00 & 7.00 & 1.00 \\
\hline 10 & 1.68 & 0 & 0 & 20.00 & 7.00 & 1.00 \\
\hline 11 & 0 & -1.68 & 0 & 11.50 & 4.00 & 1.00 \\
\hline 12 & 0 & 1.68 & 0 & 11.50 & 10.00 & 1.00 \\
\hline 13 & 0 & 0 & -1.68 & 11.50 & 7.00 & 0.00 \\
\hline 14 & 0 & 0 & 1.68 & 11.50 & 7.00 & 2.00 \\
\hline 15 & 0 & 0 & 0 & 11.50 & 7.00 & 1.00 \\
\hline 16 & 0 & 0 & 0 & 11.50 & 7.00 & 1.00 \\
\hline 17 & 0 & 0 & 0 & 11.50 & 7.00 & 1.00 \\
\hline
\end{tabular}

step change value. The matrix was a factorial design matrix with 16 response variables, four axial points, and three central points (Table 1).

The 16 response variables can be grouped into three categories: (1) sludge disintegration and organic matter released (SCOD

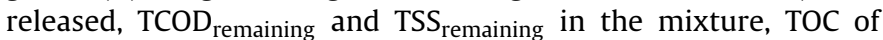
bulk solution, derived index of SCOD/TCOD); (2) process indicators (i.e., percentage of $\mathrm{H}_{2} \mathrm{O}_{2}$ remaining and $\mathrm{pH}$ value); and (3) nutrients (released ammonia, TN, and TP in bulk solution) and metals (K, Ca, $\mathrm{Mg}, \mathrm{Cu}$, and $\mathrm{Zn}$ ) released. Each response variable $Y$ was assessed as a function of three first-order effects $\left(x_{1}, x_{2}\right.$, and $\left.x_{3}\right)$, three interaction effects $\left(x_{1} x_{2}, x_{1} x_{3}\right.$, and $\left.x_{2} x_{3}\right)$, and three second-order effects $\left(x_{1}^{2}, x_{2}^{2}\right.$, and $\left.x_{3}^{2}\right)$ and can be described as follows:

$$
\begin{aligned}
Y= & \beta_{0}+\beta_{1} x_{1}+\beta_{2} x_{2}+\beta_{3} x_{3}+\beta_{11} x_{1}^{2}+\beta_{22} x_{2}^{2}+\beta_{33} x_{3}^{2}+\beta_{12} x_{1} x_{2} \\
& +\beta_{13} x_{1} x_{3}+\beta_{23} x_{2} x_{3}
\end{aligned}
$$

where $Y$ was the response variable (e.g., the percentage of sludge disintegrated or the amount of $\mathrm{H}_{2} \mathrm{O}_{2}$ remaining) and $\beta_{i}$ and $\beta_{i j}$ were coefficients. The variables and response variables were analyzed using the response surface analysis function of the Design-Expert software package and the SPSS software package (version 11.0, SPSS Inc. USA.).

\subsection{Experimental setup and treatment procedures}

Sludge pretreatment was conducted using a customized industrial microwave oven (Baoding Julong Microwave Energy Equipment Co. Ltd., China), based on our own design. The oven was operated at $600 \mathrm{~W}$ (maximum power: $1200 \mathrm{~W}$ ) at a frequency of $2450 \mathrm{MHz}$ and was equipped with a paddle-type agitator and a thermocouple temperature sensor to monitor temperatures in real time. A schematic diagram and photograph of the experimental set-up are presented in the Figs. S-1 and S-2 in supplementary information.

The volume of treated sludge was $300 \mathrm{~mL}$. The $\mathrm{pH}$ of sludge was adjusted using $1 \mathrm{~mol} / \mathrm{L} \mathrm{H}_{2} \mathrm{SO}_{4}$ or $\mathrm{NaOH}$ before heating by microwave. To offset the effects of the enzyme catalase on degradation of $\mathrm{H}_{2} \mathrm{O}_{2}$, the sludge was firstly preheated to $60^{\circ} \mathrm{C}$ by microwave irradiation, then dosed with preset amounts of hydrogen peroxide (A.R., 30\%,w/w), and heating was continued until the temperature reached $100^{\circ} \mathrm{C}$; then, the sludge was cooled in a water bath before analysis. The total heating process was conducted over a period of $5 \mathrm{~min}$, as has been reported elsewhere [26]. The sludge treatment procedure is summarized in Fig. S-3 in the supplementary information.

\subsection{Analysis}

The filtrate obtained by passing samples through a $0.45 \mu \mathrm{m}$ membrane was used to measure the concentrations of soluble substances. The concentration of residual $\mathrm{H}_{2} \mathrm{O}_{2}$ in sludge samples was determined according to the colorimetric method with $\mathrm{Ti}$ [26]. The residual $\mathrm{H}_{2} \mathrm{O}_{2}$ in the WAS was assumed to interfere strongly with the results of COD measurement; therefore, COD values were determined after removal of residual $\mathrm{H}_{2} \mathrm{O}_{2}$ by adding catalase (Sigma C9322). Total COD (TCOD), soluble COD (SCOD), TSS, VSS, ammonium, and total phosphorus (TP) were determined according to standard methods [33]. Heavy metal contents were analyzed by inductively coupled plasma atomic emission spectroscopy (ICP-AES; Optima 2000, PerkinElmer Co., USA), and soluble TOC was determined using a TOC-VCPH analyzer (Shimadzu, Japan).

\section{Results and discussion}

\subsection{Performance of sludge disintegration by the $\mathrm{MW}-\mathrm{H}_{2} \mathrm{O}_{2}$ process}

The results obtained in this study for all experimental conditions were listed in Table 2. For all 16 variables studied, these

Table 2

\begin{tabular}{|c|c|c|c|c|c|c|c|c|c|c|c|c|c|c|c|c|}
\hline Run & $\begin{array}{l}\text { SCOD } \\
(\mathrm{mg} / \mathrm{L})\end{array}$ & $\begin{array}{l}\text { TCOD } \\
(\mathrm{mg} / \mathrm{L})\end{array}$ & $\begin{array}{l}\text { TOC } \\
(\mathrm{mg} / \mathrm{L})\end{array}$ & $\begin{array}{l}\text { TSS } \\
(\mathrm{g} / \mathrm{L})\end{array}$ & $\begin{array}{l}\text { SCOD/ } \\
\text { TCOD }\end{array}$ & $\begin{array}{l}\text { VSS/ } \\
\text { TSS }\end{array}$ & $\mathrm{pH}$ & $\begin{array}{l}\mathrm{H}_{2} \mathrm{O}_{2} \text { remaining } \\
(\%)\end{array}$ & $\begin{array}{l}\mathrm{NH}_{4}{ }^{+}-\mathrm{N} \\
(\mathrm{mg} / \mathrm{L})\end{array}$ & $\begin{array}{l}\mathrm{TN} \\
(\mathrm{mg} / \mathrm{L})\end{array}$ & $\begin{array}{l}\mathrm{TP} \\
(\mathrm{mg} / \mathrm{L})\end{array}$ & $\begin{array}{l}\mathrm{K} \\
(\mathrm{mg} / \mathrm{L})\end{array}$ & $\begin{array}{l}\mathrm{Ca} \\
(\mathrm{mg} / \mathrm{L})\end{array}$ & $\begin{array}{l}\mathrm{Mg} \\
(\mathrm{mg} / \mathrm{L})\end{array}$ & $\begin{array}{l}\mathrm{Cu} \\
(\mathrm{mg} / \mathrm{L})\end{array}$ & $\begin{array}{l}\mathrm{Zn} \\
(\mathrm{mg} / \mathrm{L})\end{array}$ \\
\hline 1 & 1342 & 8029 & 418.11 & 5.13 & 0.172 & 0.74 & 4.97 & 92 & 40.93 & 44.16 & 53.15 & 40.07 & 38.27 & 76.43 & 0.16 & 1.11 \\
\hline 2 & 3152 & 18,994 & 1220.51 & 13.39 & 0.157 & 0.72 & 5.18 & 88 & 65.70 & 112.83 & 82.10 & 89.10 & 69.77 & 147.50 & 0.34 & 1.38 \\
\hline 3 & 2007 & 6884 & 684.33 & 5.01 & 0.257 & 0.66 & 7.05 & 83 & 27.15 & 55.34 & 41.38 & 37.97 & 6.81 & 41.09 & 0.30 & 0.33 \\
\hline 4 & 4125 & 15,670 & 1654.82 & 11.54 & 0.206 & 0.66 & 6.33 & 90 & 60.12 & 142.24 & 62.40 & 71.62 & 13.49 & 81.23 & 0.50 & 0.34 \\
\hline 5 & 1736 & 7992 & 570.24 & 4.76 & 0.223 & 0.73 & 4.95 & 96 & 35.44 & 60.06 & 51.38 & 38.92 & 34.45 & 68.36 & 0.19 & 1.15 \\
\hline 6 & 3436 & 15,269 & 1395.24 & 10.01 & 0.172 & 0.71 & 4.94 & 85 & 57.19 & 138.76 & 81.19 & 72.24 & 54.01 & 123.29 & 0.36 & 1.51 \\
\hline 7 & 2574 & 6687 & 902.15 & 4.47 & 0.330 & 0.64 & 6.28 & 87 & 39.81 & 85.16 & 47.95 & 35.11 & 8.81 & 40.07 & 0.26 & 0.24 \\
\hline 8 & 5504 & 14,992 & 2200.30 & 9.10 & 0.275 & 0.62 & 5.75 & 75 & 53.50 & 200.23 & 76.29 & 72.57 & 24.00 & 91.01 & 0.46 & 0.44 \\
\hline 9 & 1699 & 3393 & 296.04 & 2.02 & 0.468 & 0.67 & 6.53 & 95 & 15.45 & 28.75 & 37.19 & 12.95 & 5.58 & 22.84 & 0.18 & 0.26 \\
\hline 10 & 5061 & 17,197 & 1745.24 & 12.30 & 0.209 & 0.69 & 5.69 & 72 & 47.60 & 221.19 & 72.30 & 63.38 & 26.47 & 87.61 & 0.59 & 0.55 \\
\hline 11 & 2143 & 14,678 & 802.42 & 8.55 & 0.154 & 0.74 & 4.39 & 94 & 57.05 & 85.91 & 79.98 & 72.56 & 69.76 & 138.95 & 0.33 & 2.69 \\
\hline 12 & 3485 & 10,886 & 1300.29 & 6.38 & 0.250 & 0.58 & 6.77 & 73 & 58.58 & 123.93 & 53.00 & 75.73 & 7.70 & 57.15 & 0.38 & 0.16 \\
\hline 13 & 1613 & 12,782 & 585.66 & 11.10 & 0.116 & 0.70 & 7.36 & - & 33.50 & 57.58 & 52.85 & 59.89 & 5.57 & 49.55 & 0.09 & 0.19 \\
\hline 14 & 3620 & 10,664 & 1436.73 & 5.90 & 0.260 & 0.61 & 5.67 & 84 & 48.05 & 145.06 & 67.55 & 61.69 & 20.79 & 84.56 & 0.35 & 0.51 \\
\hline 15 & 2906 & 11,132 & 1100.03 & 7.40 & 0.209 & 0.65 & 6.05 & 80 & 55.39 & 106.45 & 58.31 & 57.98 & 15.73 & 76.99 & 0.29 & 0.35 \\
\hline 16 & 2832 & 10,713 & 1040.98 & 7.81 & 0.204 & 0.65 & 6.09 & 81 & 49.26 & 102.15 & 53.56 & 56.35 & 14.17 & 72.96 & 0.24 & 0.32 \\
\hline 17 & 2857 & 10,442 & 1087.26 & 7.61 & 0.205 & 0.65 & 6.15 & 82 & 49.17 & 102.31 & 56.59 & 57.24 & 14.96 & 76.11 & 0.29 & 0.21 \\
\hline
\end{tabular}

Experimental parameters, results, and data analysis in the CCD design for sludge pretreatment by $\mathrm{MW}-\mathrm{H}_{2} \mathrm{O}_{2}$. 
results were subjected to analysis of variance (ANOVA) to determine second-order equations that incorporated the interactions between the three variables, and the coefficients $\left(\beta_{0}, \beta_{1}-\beta_{23}\right)$ for each variable were calculated and fitted to quadratic models. The ANOVA F-value describes the significance of individual factors and their interactions, whereas the $P$-value illustrates the significance of the coefficient.

The increase of SCOD in bulk solution has been shown to be an ideal [14] and priority index for evaluating the disruption of complex WAS floc structures and reutilization of sludge. Prediction of released SCOD is a key issue in the further research and application; it was conducted based on the results obtained and the simulation conducted according to Eq. (2). Analysis of variance (ANOVA) showed that the models (Table 3 ) were statistically good (i.e., the probability for the regression is significant at $95 \%$ for $p<0.0001)$. The predicted values are relatively close to the observed values $\left(R^{2}=0.98\right)$, indicating that the developed model successfully describes the correlation between the factors and the SCOD released. Moreover, $x_{1}, x_{2}, x_{3}$, and $x_{1}^{2}$ were all found to be significant. The adequate precision value (Table 3 ) was adopted as a measure of the signal-to-noise ratio; in particular, it compares the range of predicted values at the design points to the average prediction error. Here, this value was found to be 19.99, which indicates an adequate signal, considering that a ratio greater than 4 was desirable [34].

For SCOD released, the coefficient of variance $(\mathrm{CV})$ was found to be $8.75 \%$; thus, the model can be considered to predict the observed data reasonably well, indicating good model reproducibility. The coefficients of the quadratic model in Eq. (2) were calculated by least-squares multi-linear regression analysis, and the model's goodness of fit was investigated by determining the $R^{2}$ coefficient. The resulting quadratic model can be considered suitable to describe the impacts of the three selected variables (TSS, $\mathrm{pH}$, and ratio of $\mathrm{H}_{2} \mathrm{O}_{2}$ to sludge) during sludge disintegration by AOP incorporating $\mathrm{MW}$ and $\mathrm{H}_{2} \mathrm{O}_{2}$.

Based on Eq. (2) and Table 4, Eqs. (3) and (4) were produced for coded and actual SCOD released, respectively.

$$
\begin{aligned}
\operatorname{SCOD}= & 2826.26+1040.65 x_{1}+498.01 x_{2}+439.24 x_{3} \\
& +192.41 x_{1} x_{2}-87.44 x_{1} x_{3}+158.54 x_{2} x_{3}+191.75 x_{1}^{2} \\
& -8.51 x_{2}^{2}-78.17 x_{3}^{2}
\end{aligned}
$$

$$
\begin{aligned}
\text { SCOD }= & 1544.07-145.63 \times \mathrm{TSS}-79.76 \times \mathrm{pH}-197.72 \times \mathrm{H}_{2} \mathrm{O}_{2} \\
& +21.34 \times \mathrm{TSS} \times \mathrm{pH}+29.34 \times \mathrm{TSS} \times \mathrm{H}_{2} \mathrm{O}_{2}+150.23 \times \mathrm{pH} \\
& \times \mathrm{H}_{2} \mathrm{O}_{2}+7.51 \times \mathrm{TSS}^{2}-2.68 \times \mathrm{pH}^{2}-223.33 \times \mathrm{H}_{2} \mathrm{O}_{2}^{2}
\end{aligned}
$$

Eq. (4) represents the actual factors in their original units. According to Eq. (3), the highest values of $\beta_{i}$ were found between TSS concentration and SCOD released, suggesting that the release of organic matter is controlled primarily by sludge concentration. Moreover, all values of $\beta_{i}$ were positive, indicating that the amount of organic matter released increases with increasing sludge concentration, $\mathrm{H}_{2} \mathrm{O}_{2}$ dosage, and $\mathrm{pH}$. The low values of $\beta_{i j}$ indicate that the effects of interaction among the selected variables are not pronounced, which is supported by the F-values obtained when interaction between variables was considered (Table 3 ).

To verify the representativeness and applicability of the model, experimental results in this and other studies were compared with the model-predicted values. Treatment temperature was not considered as a controlling factor in this study, because this research aimed primarily to investigate an atmospheric pressure system; however, it has been shown previously that $100^{\circ} \mathrm{C}$ is the optimal temperature [26], considering the cost involved in the complex
Table 3

Analysis of variance tables for SCOD released in bulk solution.

\begin{tabular}{llrlll}
\hline Source & Sum of squares & Df & Mean square & $F$-value & $P$-value \\
\hline Model & $22,024,707.94$ & 9.00 & $2,447,189.77$ & 36.76 & $<0.0001$ \\
$x_{1}(\mathrm{TSS})$ & $14,789,601.05$ & 1.00 & $14,789,601.05$ & 222.17 & $<0.0001$ \\
$x_{2}(\mathrm{pH})$ & $3,387,046.67$ & 1.00 & $3,387,046.67$ & 50.88 & 0.0002 \\
$x_{3}\left(\mathrm{H}_{2} \mathrm{O}_{2}\right)$ & $2,634,780.63$ & 1.00 & $2,634,780.63$ & 39.58 & 0.0004 \\
$x_{1} x_{2}$ & $296,161.32$ & 1.00 & $296,161.32$ & 4.45 & 0.0729 \\
$x_{1} x_{3}$ & $61,584.71$ & 1.00 & $61,584.71$ & 0.93 & 0.3682 \\
$x_{2} x_{3}$ & $201,088.97$ & 1.00 & $201,088.97$ & 3.02 & 0.1258 \\
$x_{1}^{2}$ & $414,516.35$ & 1.00 & $414,516.35$ & 6.23 & 0.0413 \\
$x_{2}^{2}$ & 817.07 & 1.00 & 817.07 & 0.01 & 0.9149 \\
$x_{3}^{2}$ & $68,890.69$ & 1.00 & $68,890.69$ & 1.03 & 0.3429 \\
Residual & $465,972.88$ & 7.00 & $66,567.55$ & & \\
Lack of fit & $463,142.73$ & 5.00 & $92,628.55$ & 65.46 & 0.0151 \\
Pure error & 2830.15 & 2.00 & 1415.08 & & \\
Cor. total & $22,490,680.82$ & 16.00 & & & \\
Std. dev. & 258.01 & & & $R^{2}$ & 0.98 \\
Mean & 2946.67 & & & CV $(\%)$ & 8.76 \\
Adeq. precision & 19.99 & & & PRESS & $3,694,847$
\end{tabular}

Df: degrees of freedom; Cor. total: totals of all information corrected for the mean; Adeq. precision: adequate precision; PRESS: predicted residual error sum of squares.

operation of the sealing and anti-explosion system, which is a prerequisite for pretreatment at $120^{\circ} \mathrm{C}$. As the performance of sludge disruption at $120^{\circ} \mathrm{C}$ was similar to that at $100^{\circ} \mathrm{C}$ under the experimental conditions considered here [35], it is possible to extent the applicability of this model to the medium temperatures (e.g., $120^{\circ} \mathrm{C}$ ) within a pressured system. For the treatment material, sewage sludge and the extracted activated sludge cells (which are EPS-free [36]) were compared together, and SCOD released was selected to allow comparison between previously published results. Studies investigating the effects of the $\mathrm{MW}-\mathrm{H}_{2} \mathrm{O}_{2}$ sludge pretreatment process on SCOD release were selected carefully (Fig. 1), and suggest that the interference of residual $\mathrm{H}_{2} \mathrm{O}_{2}$ that could be removed by catalase [26] or sodium carbonate [37] should be considered. The predicted results were calculated according to Eqs. (1) and (3) (associated data and calculations are presented in the supporting information). Although the treatment conditions for the three main treatment factors varied widely, the predicted SCOD released corresponded well to the experimental data (Fig. 1).

The Pearson correlation coefficient between the data obtained from published studies and the predictive model was 0.916 , with a significance level of 0.99 , according to the reference line (Fig. 1). However, TSS was found to vary between studies, and $\mathrm{pH}$ and $\mathrm{H}_{2} \mathrm{O}_{2}$ dosages have not always been investigated accurately. Nevertheless, the developed model ties these variables together well, providing a link between different treatment techniques with different TSS, $\mathrm{pH}$, and $\mathrm{H}_{2} \mathrm{O}_{2}$ dosage.

\subsection{Quadratic models for all response variables}

Using the same analysis procedure used to describe the amount of SCOD released, a quadratic model incorporating the other 15 response variables was constructed based on the results listed in Table 2. The regression coefficients and relevant statistical parameters of all 16 response variables were obtained from the ANOVA for the predictive models of sludge disintegration, as shown in Table 4. An independent predictive model was constructed for each selected response variable by substituting into Eq. (2). According to the ANOVA analysis, the regression models were significant with respect to a preset confidence level $(p<0.05)$. In this study, $R^{2}$ ranged from 0.864 (for $\mathrm{NH}_{4}-\mathrm{N}$ released) to 0.991 (for $\mathrm{TCOD}_{\text {remaining }}$ in solution) and demonstrated a good fit between the quadratic model and the experimental data.

The relative contribution of each variable $\left(x_{i}, x_{i j}, x_{i}^{2}\right)$ to each dependent response variable $\left(Y_{1}-Y_{16}\right)$ can be measured directly by the respective coefficient in the fitted model. The positive 


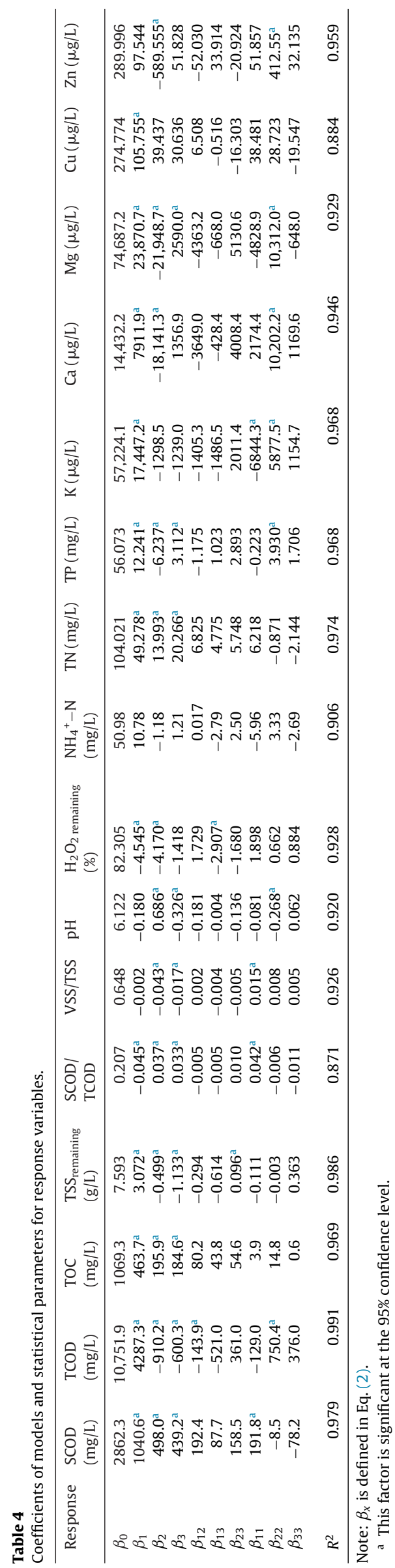

coefficients in the fitted models for $Y_{1}-Y_{16}$ indicate that the degree of sludge disintegration is closely related to the rate of change of factors $x_{3}$ (i.e., the $\mathrm{H}_{2} \mathrm{O}_{2}$ to sludge ratio) and $x_{2}(\mathrm{pH})$. Moreover, based on these results, the contributions of three first-order effects $\left(x_{1}, x_{2} x_{3}\right)$, three interaction effects $\left(x_{1} x_{2}, x_{1} x_{3}\right.$, and $x_{2}$ $\left.x_{3}\right)$, and three second-order effects $\left(x_{1}^{2}, x_{2}^{2}\right.$, and $\left.x_{3}^{2}\right)$ to the results were ranked based on the obtained coefficients, i.e., the values obtained for $\beta_{i}$. In Table 4 , the coefficients obtained for all 16 models provide information about the influence of each independent variable on each response variable. For example, for TN released, the coefficient for coded TSS $\left(x_{1}\right)$ is 49.28 ; this is the largest coefficient obtained, suggesting that TSS is the dominant factor controlling the amount of TN released in these selected ranges for all factors.

Several previous studies have considered model simulation of MW sludge pretreatment $[15,21,22,38,39]$. For example, Yang et al. [38] constructed a quadratic model to investigate the effects of combined alkaline and microwave pretreatment with two variables (different $\mathrm{pH}$ and specific energy input by RSM. Similarly, Abelleira et al. [39] determined the effect of thermal treatment and hydrogen peroxide $\left(\mathrm{H}_{2} \mathrm{O}_{2}\right)$ addition on sludge solubilization and organic matter removal by RSM. Because these empirical models were second-order polynomial models, they were validated satisfactorily, with high $\mathrm{R}^{2}$ values (i.e., $>0.9$ ). The unifying model developed in the present study was possible to simulate the versatile uses of the $\mathrm{MW}$ irradiation technique in sludge treatment, e.g., $\mathrm{MW}, \mathrm{MW}-\mathrm{H}_{2} \mathrm{O}_{2}$. MW-acid MW-alkaline and recently proposed $\mathrm{MW}-\mathrm{H}_{2} \mathrm{O}_{2}$-alkaline. Response variables of this model covered the characteristics of sludge, sludge treatment process indicators, nutrients and metals released. This unifying (AOP) model was verified by experimental data obtained from the existing literature $[20,26,29,31,35,36]$, which was provided in Table S-1 in supplementary information. This model can be used as a tool to predict the microwave (or hybrid) treatment performance for any given values of TSS, $\mathrm{H}_{2} \mathrm{O}_{2}$, and $\mathrm{pH}$. It was also possible to compare treatment procedure with same factors among different studies. For example, the plotting of data points (Fig. 1) below the reference line (for the $120^{\circ} \mathrm{C}$ treatment) [35] suggests that the method described here performs better than mild MW treatment. Thus, the model can be used for both empirical estimation and the design of the microwave-hydrogen peroxide pretreatment process in future.

\subsection{Optimization of the $\mathrm{MW}-\mathrm{H}_{2} \mathrm{O}_{2}$ process for organic matter release}

To improve understanding of the parameter of SCOD released in bulk solution, the predictive models have been presented as three-dimensional response surface plots and contour plots (Fig. 2). Pairs were formed from the variables $\left(x_{1}, x_{2}\right.$, and $\left.x_{3}\right)$, keeping the third variable fixed at its central value, e.g., the ratio of $\mathrm{H}_{2} \mathrm{O}_{2}$ to TSS was maintained constant while sludge $\mathrm{pH}$ was varied. When being held constant, the $\mathrm{H}_{2} \mathrm{O}_{2}$ ratio, TSS, and $\mathrm{pH}$ were $1,11.5 \mathrm{~g} / \mathrm{L}$, and 7 , respectively. The results suggest that the released SCOD increased in response to high sludge concentrations and $\mathrm{H}_{2} \mathrm{O}_{2}$ dosages. The maximum COD released appeared in the corner of the matrix, coinciding with higher TSS, $\mathrm{pH}$, and $\mathrm{H}_{2} \mathrm{O}_{2}$ dosage. The $p$-value of model effects $x_{1} x_{2}, x_{1} x_{3}, x_{2} x_{3}$ were greater than 0.05 $(0.0729,0.3682,0.1258$ respectively), indicating that the interaction between the three variables (TSS, $\mathrm{H}_{2} \mathrm{O}_{2}$ ratio and initial $\mathrm{pH}$ ) did not have a significant effect on the COD released.

In the present study, based on the optimization of $\mathrm{H}_{2} \mathrm{O}_{2}$ content and $\mathrm{pH}$ for the microwave-based pretreatment, the optimal values of these three parameters fell within the experimental range. The percentage of sludge disintegration increases monotonically with increasing energy input, $\mathrm{H}_{2} \mathrm{O}_{2}$ dose, and $\mathrm{pH}$. The recommended values for TSS, the $\mathrm{H}_{2} \mathrm{O}_{2}$ to sludge ratio, and $\mathrm{pH}$ were determined to be 


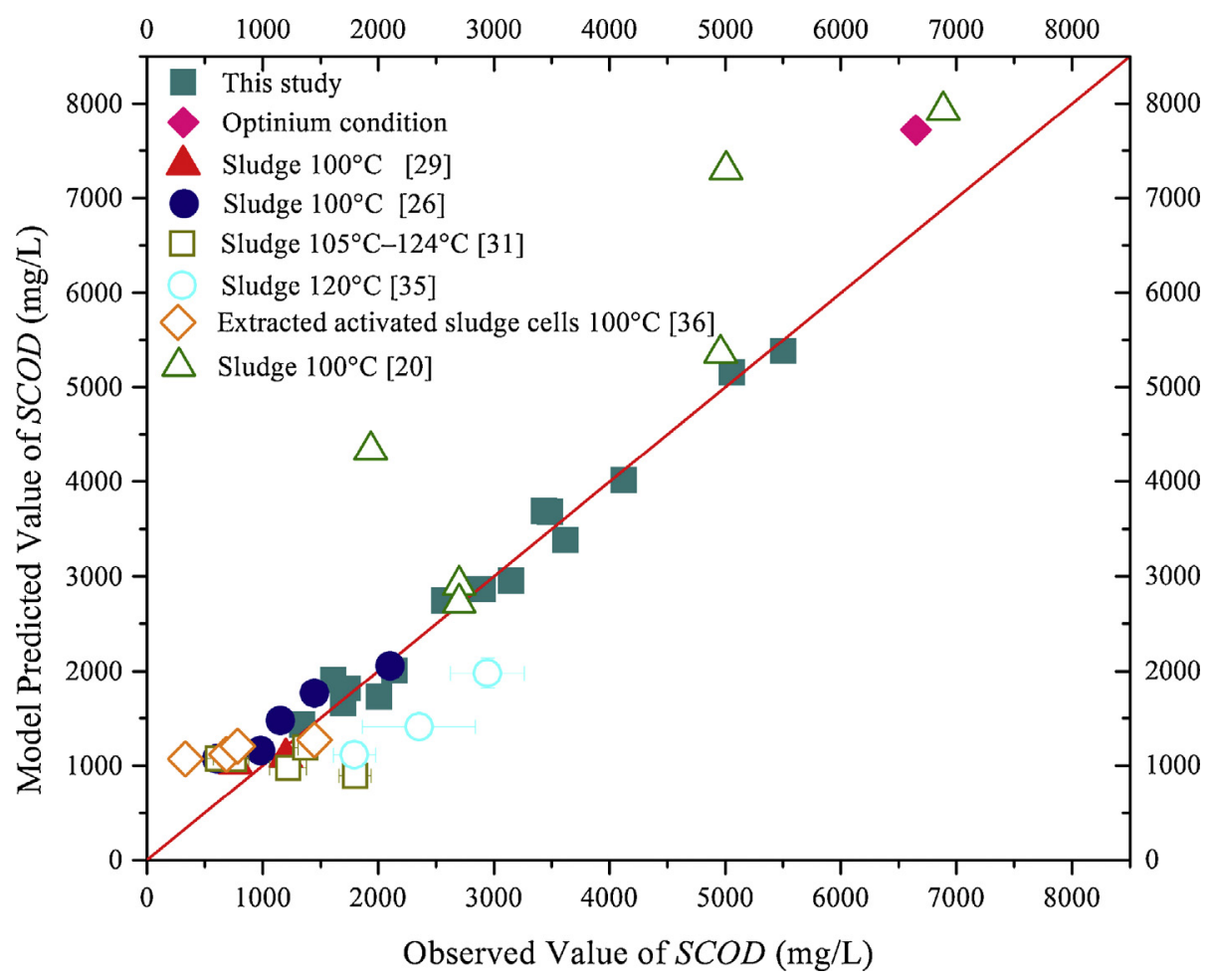

Fig. 1. Verification of values predicted by RSM with respect to observed SCOD released.

$20 \mathrm{~g} / \mathrm{L}, 2$, and 10 , respectively; these optimal values were verified by experimental study (Fig. 1), and fall within the boundaries of experimental conditions.

TSS was found to be a key factor for most of the response variables in this study (Table 4), for example, the maximum SCOD/TCOD (0.468) was achieved in the lowest TSS (Run 9). The coefficient $\beta_{1}$ for SCOD/TCOD was -0.045 , it indicated that low sludge concentration was better than high sludge concentration for improvement of SCOD/TCOD ratio under mild temperature. This result is consistent with results and a linear model reported previously in the literature [21]. They found TSS (or water content) was the most important factor that influenced the solubilization of solid materials [40]. However, water has a high thermal capacity and can absorb more energy with a relatively small increase in temperature. More energy would be consumed in raising the temperature of water at higher water contents, which decreases the efficiency of energy in the solubilization of solids. Thus, increasing the concentration of sludge treated can significantly reduce energy consumption and overall operating costs, especially in large-scale applications. The maximum sludge concentrations achieved to date for microwave pretreatment in closed-vessel systems were as high as $34 \mathrm{~g} / \mathrm{L}$ [40] and $118.5 \mathrm{~g} / \mathrm{L}$ [22]; such high sludge concentrations typically require less energy consumption per unit of dry sludge. Thus, high TSS is recommended considering the economic feasibility of MW pre-treatment process, In the hybrid process ( with $\mathrm{H}_{2} \mathrm{O}_{2}$ ) of an open system, the control and elimination of overflowing foam requires further study, particularly when used to treat very high concentrations of sludge owing to the of undesirable heavy foam.

$\mathrm{H}_{2} \mathrm{O}_{2}$ dosage is known to play an important role in breaking down the structure of sludge and increasing the amount of organic matter released into bulk solution $[20,26,41]$. Because of the catalase in sludge, $\mathrm{H}_{2} \mathrm{O}_{2}$ cannot be used as other oxidant $\mathrm{O}_{3}$ or $\mathrm{Cl}_{2}$ to solubilize the sludge directly, and usually used together with $\mathrm{Fe}$ as Fenton reaction [34]. In a previous study, catalase activity was suppressed in microwave treatment firstly, then microwave facilitated the hydroxyl radicals $(\mathrm{OH} \cdot)$ formation through the decomposition of $\mathrm{H}_{2} \mathrm{O}_{2}$, enhancing both the oxidation and particulate COD disintegration of WAS samples [14]. For example, sewage sludge was found to release $46.8 \%$ of TCOD after $\mathrm{MW}-\mathrm{H}_{2} \mathrm{O}_{2}$ treatment for $5 \mathrm{~min}$ (run 9 in Table 2); conversely, only $11.6 \%$ of SCOD was released for MW treatment only $\left(100^{\circ} \mathrm{C}\right.$, Run 13$)$ without $\mathrm{H}_{2} \mathrm{O}_{2}$. Kenge et al. [20] recommended that the ratio of $\mathrm{H}_{2} \mathrm{O}_{2}$ to sludge ( $\mathrm{w} / \mathrm{w}$ ) be set to 0.8 . The model derived in this study thus provides a convenient way to predict the effects of the $\mathrm{H}_{2} \mathrm{O}_{2}$ dosage and their relation to the cost of the pretreatment process. Yet the fate of $\mathrm{H}_{2} \mathrm{O}_{2}$ has received little attention in previous studies of $\mathrm{MW}-\mathrm{H}_{2} \mathrm{O}_{2}$ technology. The results of the present study suggest that the dosage of $\mathrm{H}_{2} \mathrm{O}_{2}$ has little effect on the amount of residual $\mathrm{H}_{2} \mathrm{O}_{2}$ after treatment, suggesting that $\mathrm{H}_{2} \mathrm{O}_{2}$ takes part in the reaction only partially. Although $\mathrm{H}_{2} \mathrm{O}_{2}$ is stable under acidic conditions but active under alkaline conditions, where it decomposes easily [42], over $72 \%$ of $\mathrm{H}_{2} \mathrm{O}_{2}$ remained in bulk solution in all runs of the present study. Therefore, the amount of $\mathrm{H}_{2} \mathrm{O}_{2}$ used is critical in determining the overall performances and the total costs of the pretreatment technology.

High $\mathrm{pH}$ appears to be effective in increasing the percentage of sludge disintegration, whereas low $\mathrm{pH}$ was found to be effective in reducing the amount of $\mathrm{H}_{2} \mathrm{O}_{2}$ consumed (Table 4); moreover, low $\mathrm{pH}$ was found to be favorable for the release of heavy metals and resulted in decreases in VSS/TSS for the treated sludge particles. Previous studies have shown that microwave- $\mathrm{H}_{2} \mathrm{O}_{2}$ or microwaveonly pretreatment of sludge can enhance the release of $\mathrm{NH}_{4}{ }^{+}-\mathrm{N}$ and $\mathrm{PO}_{4}{ }^{3-}-\mathrm{P}$ in acidic solutions [43]. $\mathrm{PH}$ adjustment without MW irradiation (especially alkaline treatment) could also effectively solubilize particulate organic matter in the sludge [44]. However, the treatment always takes several hours or more (typically, 3-24 h) to complete. When combined with microwave disintegration methods, this treatment was found to be highly efficient and rapid (typically completed within $30 \mathrm{~min}$ ), the organic matter released could be enhanced to the $25.0 \%$ at pH 10 (Run 12 , Table 2). The success of pH adjustment treatment depends on two main mechanisms: chemical degradation and ionization of hydroxyl groups [44]. A high extreme of $\mathrm{pH}$ leads to increased negative charge of 

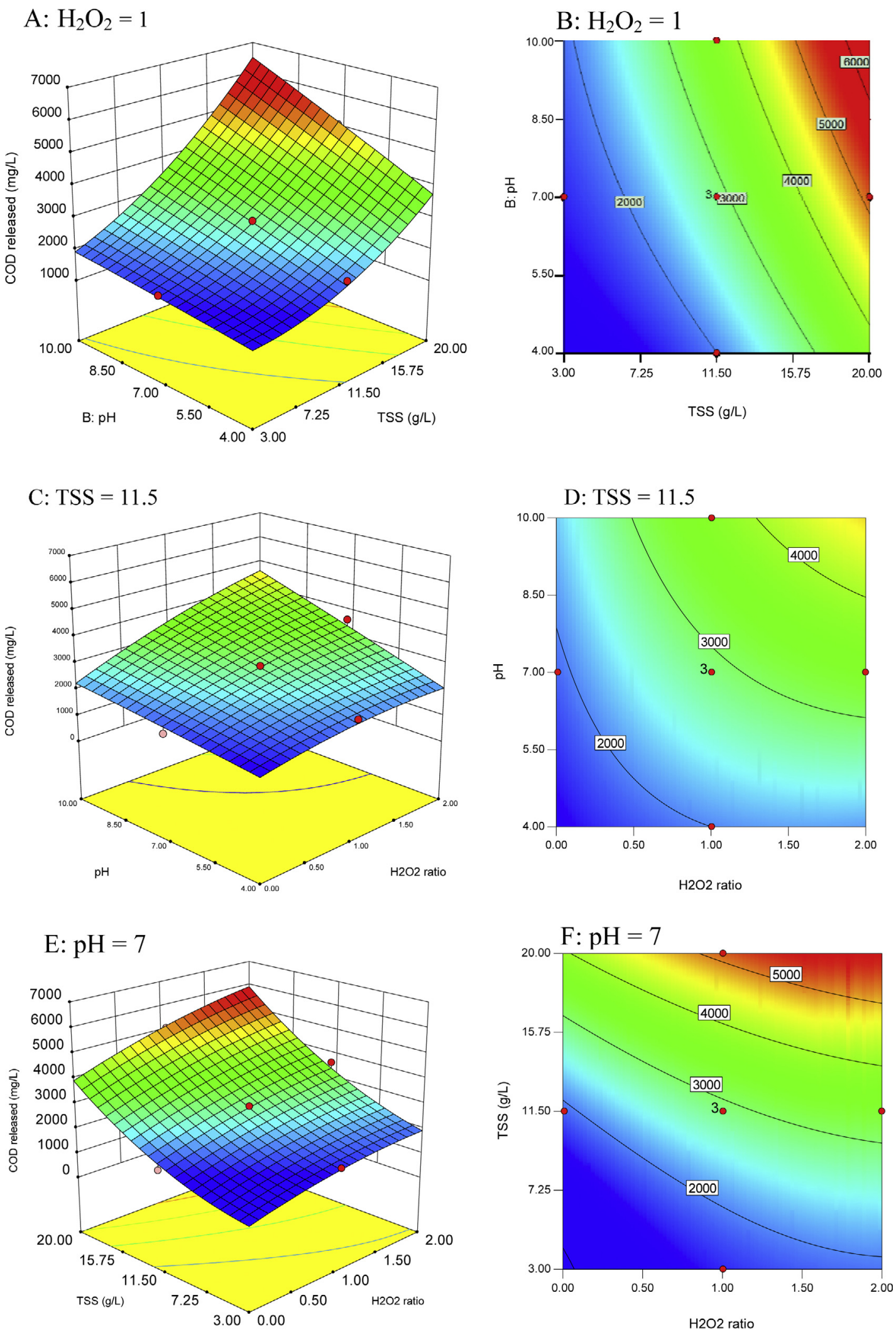

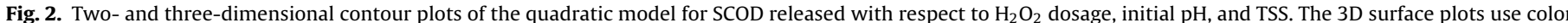

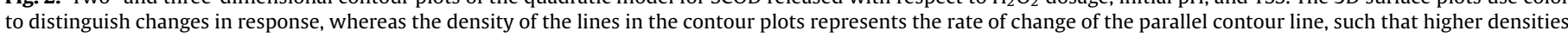
correspond to faster rates of change. 


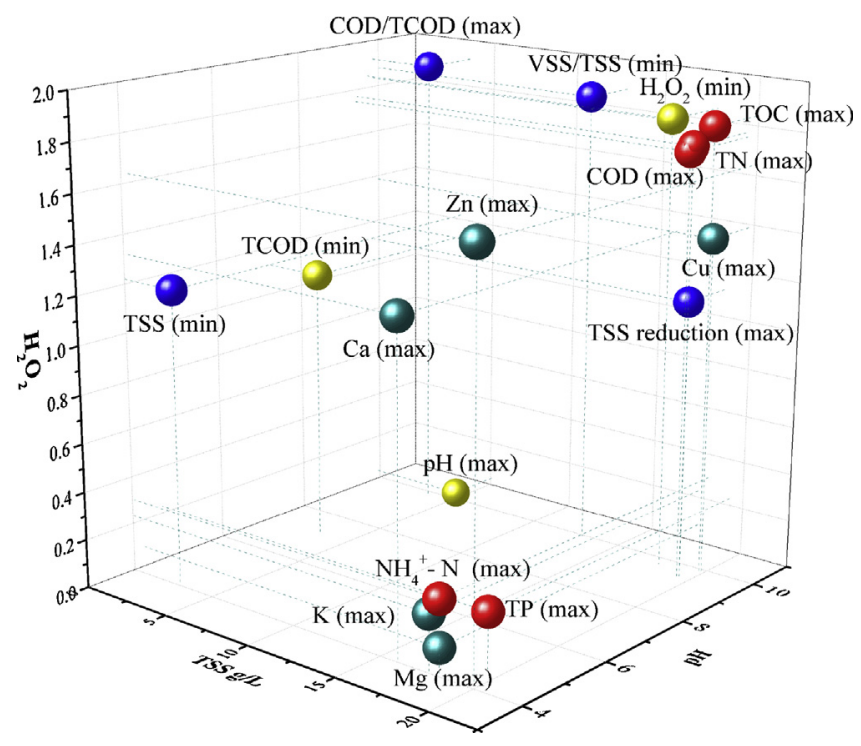

Fig. 3. The optimal conditions for 16 response variables. (Red dots) organic matters and nutrient in solution, (green dots) metals in solution, (light blue dots) treated sludge properties, (yellow dots) TCOD of mixture, $\mathrm{pH}$ and $\mathrm{H}_{2} \mathrm{O}_{2}$ in solution, min and max in parentheses represent the optimal condition for the maximum or minimum values of this variables. (For interpretation of the references to color in this legend, the reader is referred to the web version of the article.)

bacterial surfaces, and the stability of $\mathrm{H}_{2} \mathrm{O}_{2}$ is influenced strongly by $\mathrm{pH}$. During the $\mathrm{MW}-\mathrm{H}_{2} \mathrm{O}_{2}$ oxidation, the rate of generation and consumption of hydroxyl radicals (which form at $\mathrm{pH}>8$ ) is strongly influenced by $\mathrm{pH}$. The MW pretreatment facilitates the hydrolysis of polymer and compounds with poor biodegradability [45] to produce simpler compounds that can be more readily biodegradable [46]. In the present study, the final $\mathrm{pH}$ of pretreated sludge was found to be notably lower than the initial pH (Table 2), possibly owing to dissolution of carboxylic acids and volatile fatty acids generated by complex organic matter in association with cell lysis $[47,48]$ in the initial high-pH group. Thus, the final pH of slurry may remain within the natural range, which will be beneficial for subsequent treatment of sludge. In the group without $\mathrm{pH}$ control, weak acidic products (e.g., VFA) [49] generated by $\mathrm{MW}-\mathrm{H}_{2} \mathrm{O}_{2}$ treatment may disturb the further post treatment of sludge. Nevertheless, the mechanisms by which $\mathrm{pH}$ affects the microwave $-\mathrm{H}_{2} \mathrm{O}_{2}$ sludge pretreatment process require further research.

\subsection{Optimization of the $\mathrm{MW}-\mathrm{H}_{2} \mathrm{O}_{2}$ process for multi-objectives}

The empirical validation for this experiment was satisfactory (Fig. 1). In particular, the results suggest that, to achieve optimal conditions generally, focus should be placed primarily on solubilization conducted under mild conditions (i.e., $\mathrm{H}_{2} \mathrm{O}_{2} \in[1.4,2.0]$; $\mathrm{pH} \in[8,10])$. Moreover, the model acquired from the response surfaces discussed in the previous sections provides an effective strategy to optimize the microwave/hydrogen peroxide/pH pretreatment process for multiple objectives, including anaerobic digestion, sludge leaching, and nutrient recovery. This optimization was conducted separately for each response variable (Fig. 3). The optimal treatment conditions can be decided in practice based on general predictive models and cost-benefit analysis, considering the price of the energy and $\mathrm{H}_{2} \mathrm{O}_{2}$ required for pretreatment and the economic benefits gained from sludge pretreatment. Cost-benefit analysis parameters may vary depending on the intended use. For example, recovery of resources may require more intensive treatment than sludge reduction (e.g., by requiring sludge to be transported back to aeration tanks), and the costs of the additional treatment must be taken into consideration.

The optimized treatment conditions for different responses can be clustered into three groups: (1) points including $\left(\mathrm{SCOD}_{\max }\right.$, $\mathrm{TN}_{\max }, \mathrm{TOC}_{\max }$ ), which represent the degree of sludge disintegration and plot in the region of high TSS, high $\mathrm{H}_{2} \mathrm{O}_{2}$, and high $\mathrm{pH}$, accompanied by $\mathrm{H}_{2} \mathrm{O}_{2}$ consumption and TSS reduction; (2) points indicating the degree of disintegration of the sludge itself (VSS/TSS $_{\min }$, SCOD/TCOD $\max$ ), which lie in areas of high $\mathrm{H}_{2} \mathrm{O}_{2}$ and high $\mathrm{pH}$; (3) and points based on the amounts of nutrients (except $\mathrm{TN}$ ) and metals released, where the optimal operating conditions correspond to low $\mathrm{pH}$ and low $\mathrm{H}_{2} \mathrm{O}_{2}$.

Generally, every response is associated with optimal operating conditions (involving $x_{1}, x_{2}$, and $x_{3}$ ). Field engineering reutilization applications (e.g., sludge reduction, material recovery, heavy metal leaching) have multiple engineering objectives, such that there may often be conflict between various treatment requirements, e.g., between struvite recovery (low $\mathrm{pH}$, low $\mathrm{H}_{2} \mathrm{O}_{2}$ dosage) and enhancing anaerobic digestion (high $\mathrm{pH}$, high $\mathrm{H}_{2} \mathrm{O}_{2}$ dosage). In fact, conflict may arise even for a single treatment objective; for example, to enhance the denitrification process for an external carbon source, maximum COD release (high $\mathrm{pH}$ and $\mathrm{H}_{2} \mathrm{O}_{2}$ dosage) and minimum ammonia release (low pH and $\mathrm{H}_{2} \mathrm{O}_{2}$ dosage) are desired. However, few previous studies have attempted to integrate the optimization of individual parameters into a framework for groups of optimal parameters designed to meet multiple objectives. To address this, the response can be optimized using the Design-Expert software and Modde 9.0 [39] to attribute different weights to the response variables depending on their purpose and based on model predictions (i.e., Eq. (2) and the coefficients from Table 4). Such optimization can help meet the varying requirements of sludge disintegration, even under restrictions imposed by multiple objectives.

To retain advantages over other competing sludge pretreatment techniques (e.g., mechanical, ultrasonic, ozone) and ensure favorable results in full-scale applications, microwave (and hybrid microwave) pretreatment processes must offer better performance for multiple engineering objectives simultaneously. In this context, RSM could provide a powerful tool to determine optimal conditions for such integrated multiple objectives. These models will be particularly useful in future studies of MW-enhanced advanced oxidation processes.

\section{Conclusions}

(1) The effects of $\mathrm{pH}$ (especially alkaline) on SCOD released in microwave-hydrogen peroxide pretreatment were found to be pronounced, and $\mathrm{pH}$ was shown to play an important role in determining the percentage of $\mathrm{H}_{2} \mathrm{O}_{2}$ utilized.

(2) Quadratic models were built based on statistical analysis using the RSM approach, and were found to fit the data from this experiment and the literature well; in particular, analysis of variance returned a high coefficient of determination (0.871-0.992) for all 16 response variables. The predictive model developed here was shown to be capable of optimizing the treatment process for multiple disintegration objectives.

\section{Acknowledgements}

This work was financially supported by the National Water Pollution Control and Management Technology Major Projects of China (No. 2012ZX07202-005) and the National Natural Science Foundation of China (No. 51008297). 


\section{Appendix A. Supplementary data}

Supplementary data associated with this article can be found, in the online version, at http://dx.doi.org/10.1016/j.jhazmat.2014. 10.022 .

\section{References}

[1] H. Odegaard, Sludge minimization technologies - an overview, Water Sci. Technol. 49 (2004) 31-40.

[2] Y.S. Wei, R.T. Van Houten, A.R. Borger, D.H. Eikelboom, Y.B. Fan, Minimization of excess sludge production for biological wastewater treatment, Water Res. 37 (2003) 4453-4467.

[3] I. Dogan, F.D. Sanin, Alkaline solubilization and microwave irradiation as a combined sludge disintegration and minimization method, Water Res. 43 (2009) 2139-2148.

[4] H. Shahriari, M. Warith, M. Hamoda, K.J. Kennedy, Anaerobic digestion of organic fraction of municipal solid waste combining two pretreatment modalities, high temperature microwave and hydrogen peroxide, Waste Manag. 32 (2012) 41-52.

[5] L. Appels, S. Houtmeyers, J. Degreve, J. Van Impe, R. Dewil, Influence of microwave pre-treatment on sludge solubilization and pilot scale semicontinuous anaerobic digestion, Bioresour. Technol. 128 (2013) 598-603.

[6] M.Z.M. Yusoff, A.Y. Hu, C.J. Feng, T. Maeda, Y. Shirai, M.A. Hassan, C.P. Yu, Influence of pretreated activated sludge for electricity generation in microbial fuel cell application, Bioresour. Technol. 145 (2013) 90-96.

[7] P.H. Liao, D.S. Mavinic, F.A. Koch, Release of phosphorus from biological nutrient removal sludges: a study of sludge pretreatment methods to optimize phosphorus release for subsequent recovery purposes, J. Environ. Eng. Sci. 2 (2003) 369-381.

[8] M. Carballa, F. Omil, J.M. Lema, Influence of different pretreatments on anaerobically digested sludge characteristics: suitability for final disposal, Water Air Soil Pollut. 199 (2009) 311-321.

[9] C. Bougrier, A. Battimelli, J.P. Delgenes, H. Carrere, Combined ozone pretreatment and anaerobic digestion for the reduction of biological sludge production in wastewater treatment, Ozone-Sci. Eng 29 (2007) 201-206.

[10] I. Toteci, KJ. Kennedy, R.L. Droste, Evaluation of continuous mesophilic anaerobic sludge digestion after high temperature microwave pretreatment, Water Res. 43 (2009) 1273-1284.

[11] P. Kampas, S.A. Parsons, P. Pearce, S. Ledoux, P. Vale, J. Churchley, E. Cartmell, Mechanical sludge disintegration for the production of carbon source for biological nutrient removal, Water Res. 41 (2007) 1734-1742.

[12] A.G. Vlyssides, P.K. Karlis, Thermal-alkaline solubilization of waste activated sludge as a pre-treatment stage for anaerobic digestion, Bioresour. Technol. 91 (2004) 201-206.

[13] V.K. Tyagi, S.L. Lo, Application of physico-chemical pretreatment methods to enhance the sludge disintegration and subsequent anaerobic digestion: an up to date review, Rev. Environ. Sci. Biol. 10 (2011) 215-242.

[14] V.K. Tyagi, S.L. Lo, Microwave irradiation: a sustainable way for sludge treatment and resource recovery, Renew. Sustain. Energy Rev. 18 (2013) 288-305.

[15] O.C. Xiao, H. Yan, Y.S. Wei, Y.W. Wang, F.G. Zeng, X. Zheng, Optimization of $\mathrm{H}_{2} \mathrm{O}_{2}$ dosage in microwave- $\mathrm{H}_{2} \mathrm{O}_{2}$ process for sludge pretreatment with uniform design method, J. Environ. Sci. 24 (2012) 2060-2067.

[16] M. Kuglarz, D. Karakashev, I. Angelidaki, Microwave and thermal pretreatment as methods for increasing the biogas potential of secondary sludge from municipal wastewater treatment plants, Bioresour. Technol. 134 (2013) 290-297.

[17] C. Eskicioglu, N. Terzian, K.J. Kennedy, R.L. Droste, M. Hamoda, Athermal microwave effects for enhancing digestibility of waste activated sludge, Water Res. 41 (2007) 2457-2466.

[18] Y. Hong, C. Zhenmin, W. Yawei, X. Benyi, W. Yuansong, L. Junxin, Releases of carbon, nitrogen and phosphorus from sewage sludge at different microwave energy inputs, Environ. Sci. 30 (2009) 3639-3644 (in Chinese)

[19] I. Toreci, K.J. Kennedy, R.L. Droste, Effect of high temperature microwave thickened waste-activated sludge pretreatment on distribution and digestion of soluble organic matter, Environ. Eng. Sci. 26 (2009) 981-991.

[20] A.A. Kenge, P.H. Liao, K.V. Lo, Factors affecting microwave-enhanced advanced oxidation process for sewage sludge treatment, J. Environ. Sci. Health A 44 (2009) 1069-1076.

[21] W.J. Park, J.H. Ahn, S. Hwang, C.K. Lee, Effect of output power, target temperature, and solid concentration on the solubilization of waste activated sludge using microwave irradiation, Bioresour. Technol. 101 (2010) S13-S16.

[22] I. Toreci, K.J. Kennedy, R.L. Droste, Effect of high-temperature microwave irradiation on municipal thickened waste activated sludge solubilization, Heat Transf. Eng. 31 (2010) 766-773.

[23] P.H. Liao, W.T. Wong, K.V. Lo, Advanced oxidation process using hydrogen peroxide/microwave system for solubilization of phosphate, J. Environ. Sci. Health A 40 (2005) 1753-1761.
[24] W.T. Wong, W.I. Chan, P.H. Liao, K.V. Lo, A hydrogen peroxide/microwave advanced oxidation process for sewage sludge treatment, J. Environ. Sci. Health A 41 (2006) 2623-2633.

[25] Y. Yu, W.I. Chan, P.H. Liao, K.V. Lo, Disinfection and solubilization of sewage sludge using the microwave enhanced advanced oxidation process, J. Hazard. Mater. 181 (2010) 1143-1147.

[26] Y.W. Wang, Y.S. Wei, J.X. Liu, Effect of $\mathrm{H}_{2} \mathrm{O}_{2}$ dosing strategy on sludge pretreatment by microwave- $\mathrm{H}_{2} \mathrm{O}_{2}$ advanced oxidation process, J. Hazard. Mater. 169 (2009) 680-684.

[27] G.Q. Yin, P.H. Liao, K.V. Lo, Sewage sludge treatment using microwaveenhanced advanced oxidation process, J. Environ. Sci. Health A 43 (2008) 191-201.

[28] J. Hong, N.N. Yuan, Y.X. Wang, S.H. Qi, Efficient degradation of Rhodamine $\mathrm{B}$ in microwave $-\mathrm{H}_{2} \mathrm{O}_{2}$ system at alkaline pH, Chem. Eng. J. 191 (2012) 364-368.

[29] W.I. Chan, W.T. Wong, P.H. Liao, K.V. Lo, Sewage sludge nutrient solubilization using a single-stage microwave treatment, J. Environ. Sci. Health A 42 (2007) 59-63.

[30] K.V. Lo, W.W.I. Chan, S.K. Yawson, P.H. Liao, Microwave enhanced advanced oxidation process for treating dairy manure at low pH, J. Environ. Sci. Health B 47 (2012) 362-367.

[31] W.I. Chan, P.H. Liao, K.V. Lo, Effects of irradiation intensity and pH on nutrients release and solids destruction of waste activated sludge using the microwave-enhanced advanced oxidation process, Water Environ. Res. 82 (2010) 2229-2238.

[32] H. Jung, J. Kim, S. Lee, C. Lee, Effect of mild-temperature $\mathrm{H}_{2} \mathrm{O}_{2}$ oxidation on solubilization and anaerobic digestion of waste activated sludge, Environ. Technol. 35 (2014) 1702-1709.

[33] E. China, Standard Methods for Examination of Water and Wastewater, Chinese Environmental Science Press, China, 2002.

[34] M. Ahmadi, F. Vahabzadeh, B. Bonakdarpour, E. Mofarrah, M. Mehranian, Application of the central composite design and response surface methodology to the advanced treatment of olive oil processing wastewater using Fenton's peroxidation, J. Hazard. Mater. 123 (2005) 187-195.

[35] K.V. Lo, W.I. Chan, I.W. Lo, P.H. Liao, The effects of irradiation intensity on the microwave-enhanced advanced oxidation process, J. Environ. Sci. Health A 45 (2010) 257-262.

[36] Y. Yu, I.W. Lo, W.W.I. Chan, P.H. Liao, K.V. Lo, Nutrient release from extracted activated sludge cells using the microwave enhanced advanced oxidation process, J. Environ. Sci. Health A 45 (2010) 1071-1075.

[37] T. Wu, J.D. Englehardt, A new method for removal of hydrogen peroxide interference in the analysis of chemical oxygen demand, Environ. Sci. Technol. 46 (2012) 2291-2298.

[38] Q. Yang, J. Yi, K. Luo, X.L. Jing, X.M. Li, Y. Liu, G.M. Zeng, Improving disintegration and acidification of waste activated sludge by combined alkaline and microwave pretreatment, Process Saf. Environ. 91 (2013) 521-526.

[39] J. Abelleira, S.I. Perez-Elvira, J.R. Portela, J. Sanchez-Oneto, E. Nebot, Advanced thermal hydrolysis: optimization of a novel thermochemical process to aid sewage sludge treatment, Environ. Sci. Technol. 46 (2012) 6158-6166.

[40] B. Tang, L. Yu, S. Huang, J. Luo, Y. Zhuo, Energy efficiency of pre-treating excess sewage sludge with microwave irradiation, Bioresour. Technol. 101 (2010) 5092-5097.

[41] W.T. Wong, K.V. Lo, P.H. Liao, Factors affecting nutrient solubilization from sewage sludge using microwave-enhanced advanced oxidation process, J. Environ. Sci. Health A 42 (2007) 825-829.

[42] Z. Qiang, Removal of Selected Hazardous Organic Compounds by ElectroFenton Oxidation Process, University of Delaware, Newark, 2002.

[43] W.T. Wong, W.I. Chan, P.H. Liao, K.V. Lo, D.S. Mavinic, Exploring the role of hydrogen peroxide in the microwave advanced oxidation process: solubilization of ammonia and phosphates, J. Environ. Eng. Sci. 5 (2006) 459-465.

[44] G. Erden, Combination of alkaline and microwave pretreatment for disintegration of meat processing wastewater sludge, Environ. Technol. 34 (2013) 711-718.

[45] W. Qiao, W. Wang, R. Xun, W.J. Lu, K.Q. Yin, Sewage sludge hydrothermal treatment by microwave irradiation combined with alkali addition, J. Mater. Sci. 43 (2008) 2431-2436.

[46] S.M. Hong, J.K. Park, N. Teeradej, Y.O. Lee, Y.K. Cho, C.H. Park, Pretreatment of sludge with microwaves for pathogen destruction and improved anaerobic digestion performance, Water Environ. Res. 78 (2006) 76-83.

[47] A. Shanableh, S. Jomaa, Production and transformation of volatile fatty acids from sludge subjected to hydrothermal treatment, Water Sci. Technol. 44 (2001) 129-135.

[48] A.T. Quitain, M. Faisal, K. Kang, H. Daimon, K. Fujie, Low-molecular-weight carboxylic acids produced from hydrothermal treatment of organic wastes, J. Hazard. Mater. 93 (2002) 209-220.

[49] C. Eskicioglu, A. Prorot, J. Marin, R.L. Droste, K.J. Kennedy, Synergetic pretreatment of sewage sludge by microwave irradiation in presence of $\mathrm{H}_{2} \mathrm{O}_{2}$ for enhanced anaerobic digestion, Water Res. 42 (2008) 4674-4682. 